\title{
Kesempatan Kerja Bagi Masyarakat Dengan Adanya Bali safari and Marine park Di desa Serongga, Kabupaten gianyar
}

Bernardinus Ignasius Gunawan a, 1, I Made Adikampana a, 2,

1 ignasiusgunawan@gmail.com’,2 adikampana@unud.ac.id

a Program Studi S1 Destinasi Pariwisata, Fakultas Pariwisata, Universitas Udayana, Jl. Dr. R. Goris, Denpasar, Bali 80232 Indonesia

\begin{abstract}
This paper, entitled "employment opportunities for people with the Bali Safari And Marine Park in Serongga Village, Gianyar Regency." The importance of the research carried out is to know the influence of the existence of the Bali Safari And Marine Park (BSMP) towards employment opportunities obtained village community Serongga. Data analysis technique used is descriptive-qualitative techniques, namely how the excavation information then the results are depicted in the form of words or sentences then its compilation is done systematically and accurately about the fact are there so that the result is related to the development of tourism and its influence on the employment opportunities available to the community of the village of Serongga.

Based on research results, employment opportunities obtained by the Serongga village community by having BSMP divided into two i.e. employment opportunities directly and indirectly. Immediate job opportunities divided into employment as labor contracts and as workers in art BSMP. Indirect job opportunities divided into employment opportunities as a livestock feed suppliers in the form of elephant grass and fresh vegetables as well as employment opportunities as a provider of food for the staff at BSMP
\end{abstract}

Keywords : employment, community, existence.

\section{PENDAHULUAN}

Pada era yang sangat maju seperti sekarang ini semua negara sedang gencar untuk menggali potensi pariwisata yang ada di negara mereka, karena melalui pariwisata sebuah negara mendapatkan devisa yang besar. Saat ini Indonesia berada dalam posisi dimana dengan sangat aktif sedang mempromosikan daya tarik wisata yang dimiliki, dengan bermodalkan negara kepulauan dan negara yang memiliki garis pantai terpanjang di dunia, tak heran bila negara Indonesia gencar mempromosikan wisata bahari. Dan dalam kurun waktu beberapa tahun ini terjadi peningkatan kunjungan wisatawan mancanegara ke Indonesia. Tercatat pada tahun 2016 kunjungan wisatawan mencapai dua belas juta wisatawan mancanegara dan meningkat $15 \%$ dari tahun sebelumnya.

Berbicara tentang pariwisata Indonesia tidak lengkap rasanya jika tidak berbicara tentang Pulau Bali, Pulau Bali merupakan salah satu pulau yang memiliki potensi pariwisata yang sangat besar, selain alam yang indah pantai yang memukau adat serta budaya Bali pula menjadi salah satu daya tarik tersendiri. Pengembangan pariwisata di Pulau Bali bisa dikatakan sangat pesat, dalam kurun waktu beberapa tahun saja sudah banyak sekali hotel dan juga tempat hiburan yang memenuhi sudut jalanan. Sejatinya masih banyak potensi alam maupun buatan yang dapat dikembangkan kembali di Pulau Bali yang mana jikalau nanti optimal dapat meningkatkan kesejahteraan masyarakat.

Bali memiliki tujuh kabupaten dan satu kota dan salah satu kabupaten yang memiliki potensi serta adat yang sangat kuat adalah Kabupaten Gianyar, banyak sekali daya tarik wisata yang dapat kita jumpai di Gianyar. Desa Serongga merupakan salah satu desa yang terletak di Kabupaten Gianyar, walapun Desa Serongga tidak memiliki potensi pariwisata alam yang banyak seperti desa yang lain, tetapi di Desa Serongga lah salah satu daya tarik yang sangat terkenal di Bali berada, yakni Bali Safari and Marine Park. BSMP merupakan kebun binatang ketiga yang dikelola oleh PT. Taman Safari Indonesia yang dimana sebelumnya sudah beroperasi di Pulau Jawa.

BSMP berada di lokasi yang strategis tepatnya hanya 30 menit dari Kota Denpasar, luas keseluruhan dari BSMP mencapai 40 hektar, BSMP resmi beroperasi pada tahun di 2007 yang dimana diresmikan secara langsung oleh Presiden kala itu yakni Bapak Sosilo Bambang Yudhoyono. Sedari rencana awal BSMP ini menciptkan suatu kebun binatang 
yang bernuansa alam sehingga menerapkan tema safari yang dimana hewan hidup secara bebas tanpa kandang dan dapat berinteraksi secara langsung dengan wisatawan. Dan selain itu BSMP juga menyelipkan adat dan budaya Bali yang dimana berguna sebagai hiburan dan juga pembelajaran, untuk harga tiket masuknya sediri mulai dari seratus lima puluh ribu rupiah

Tentunya dengan dibukanya BSMP pada 2007 membawa angin segar bagi masyarakat Desa Serongga. Dan hingga kini hampir 12 tahun berlalu BSMP sudah sangat jauh berbeda dan berkembang sangat pesat, tentunya perlu dilihat kembali kesempatan kerja apa saja yang telah di sediakan atau dibuka bagi masyarakat di Desa Serongga, yang dimana pekerjaan tersebut dapat memberikan dampak ekonomi bagi masyarakat.

\section{KEPUSTAKAAN}

Dengan adanya daya tarik wisata di suatu daerah secara tidak langsung pasti memberikan dampak ekonomi, khususnya dengan adanya kesempatan kerja yang tercipta. Hal tersebut dapat dibuktikan dari penelitian sebelumnya yang berjudul "Optimalisasi kontribusi pariwisata Ceking Terhadap ekonomi masyarakat lokal. Terjadi suatu permasalahan dimana masyarakat local tidak menerima secara maksiaml kontribusi dengan adanya pariwisata di daerah mereka, dan cenderung kurang memperhatikan keberlangsungan dari pariwisata (Adikampana 2012).

Penelitian selanjutnya yang dilaksanakan oleh (Abadi 2010) Hasil dari penelitian tersebut memaparkan factor-faktor yang mempengaruhi masyarakat untuk berdagang di wisata dan Makam Bung Karno adalah untuk mendapatkan pengasilan, karena sangat sedikit kesempatan kerja yang dapat di serap oleh warga dengan adanya daya tarik wisata tersebut.

Dalam artikel kesempatan kerja bagi masyarakat dengan adanya BSMP kan berlandaskan dari lima konsep yang dimana nantinya akan digunakan sebagai pedoman bagi penulis untuk menjawab rumusan yang ada dalam penelitian ini, kelima konsep tersebut terdiri dari ;

\section{Konsep Kesempatan Kerja}

Kesempatan kerja dapat memiliki arti sebagai suatu lapangan usaha yang timbul atau terjadi karena adanya suatu kegiatan ekonomi baik itu barang atau jasa, disini juga kesempatan kerja mencangkup lapangan kerja yang sudah terisi oleh karyawan atau dapat pula diartika sebagai salah satu kontribusi dalam pembangunan Sagir(1994;52)

Dalam penelitian ini akan dilihat kesempatan kerja apa saja yang telah tercipta dengan adanya BSMP, yang dimana membawa perubahan ekonomi bagi masyarakat Desa Serongga.

\section{Konsep Perubahan Mata Pencaharian}

Dalam pengertian dari KBBI (Kamus Besar Bahasa Indonesia) pencaharian adalah suatu upaya yang dilakukan oleh seseorang untuk memenuhi kebutuhan primer mereka, sedangkan untuk pengertian mata pencaharian disini ialah upaya yang dilakukan seseorang unutuk berupaya meningkatkan taraf atau standar hidup mereka yang tentunya dimana kebutuhan hidup di setiap daerah pasti berbeda.

Dengan berkembangnya pariwisata, banyak masyarakat lokal yang menjadi petani beralih profesi menjadi pekerja pariwisata. Dimana masyarakat menganggap bekerja di pariwisata lebih cepat menghasilkan uang, bersih, dan karena berinteraksi dengan wisatawan.

Dengan adanya kesempatan kerja baru, tentunya terjadi perubahan mata pencaharian. Yang dimana akan dilihat apakah perubahan mata pencaharian tersebut memberikan dampak positif atau tidak.

\section{Konsep Daya Tarik Wisata}

Pengertian pariwisata merupakan seluruh kegiatan yang bertujuan untuk mendapatkan hiburah atau refreshing yang dimana didalamnya mengunakan fasilitas untuk mendukung kegiatan tersebut dan yang disediakan oleh masyarakat lokal, investor atapun pemerintah setempat, selanjutnya untuk pengertian daya tarik wisata adalah sesuatu yang yang terlihat dan dapat dirasakan yang dimana didalamnya memiliki keunikan maupun keindahan serta nilai dari keberagaman alam, budaya, maupun buatan dari manusia yang dimana dapat memikat seseorang untuk datang berkunjung. Undang-Uundang nomor sepuluh tahun 2009

Tentunya daya tarik wisata dalam penelitian ini adalah BSMP, dengan adanya BSMP akan dilihat perubahan apa saja yang terjadi khususnya dalam kesempatan kerja. 


\section{Konsep Masyarakat}

Jika melihat kata masyarakat berarti society dalam Bahasa inggris, sejatinya kata masyarakat berasal dari Bahasa timur tengah yakni syarakayang yang dapat juga diartikan sebagai keikutsertaan. Bila diartikan secara umum masyarakat dapat diartikan sebagai beberapa atau kumpulan orang yang saling berinteraksi dan bergaul dan mereka berharap agar hubungan mereka dapat terus berjalan.

Masyarakat Desa Serongga tentunya merupakan yang merasakan secara langsung dampak dari adanya BSMP terutama dalam hal kesempatan kerja, mereka lah yang akan memilai apakah dengan adanya BSMP kesempatan kerja yang tercipta lebih besar atapun tidak ada sama sekali.

\section{Konsep Penyerapan Tenaga Kerja}

Penyerapan tenaga kerja dapat diartikan sebagai sebagian dari jumlah tenaga kerja yang ikut berkontibusi dalam sebuah kegiatn usaha tertentu, selain itu tenaga kerja juga dapat diartikan sebagai jumlah pekerja yang ada disuatu perusahaan. Adanya permintaan suatu tenaga kerja sangat tergantung dari kebutuhan masing-masing perusahaan atau kegiatan usaha, adapun beberapa faktor yang mempengaruhi permitaan tenaga kerja adalah perubahan upah dan juga permintaan hasil produksi. Bila dikaitkan dengan penjelasan diatas dapat diartikan permintaan tenaga kerja adalah suatu hubungan antara upah dan juga jumlah tenaga kerja yang diperlukaan oleh suatu perusahaan. Jadi yang dimaksud dengan penyerapan tenaga kerja pada artikel ini adalah jumlah atau banyaknya masyarakat Desa Serongga dengan adanya BSMP.

\section{METODE PENELITIAN}

Lokasi dari penelitian ini berada di Desa Serongga, Kecamatan Gianyar, Kabupaten Gianyar. Jenis data yang digunakan dalam penelitian ini yaitu data kualitatif yang berupa hasil wawancara dengan pihak yang terkait serta keterangan mengenai gambaran umum misalnya tentang study dokumentasi, diskusi terfokus atau observasi yang dituangkan dalam catatan lapangan (transkip). Bentuk lain dari penelitian kualitatif ialah gambar yang diperoleh dari hasil pemotretan atau rekaman video mengenai Data Kualitatif dalam penelitian ini meliputi gambaran umum Desa Serongga. Sedangkan data kuantitatifnya berupa kunjungan wisatawan.

Adapun Sumber data yang diterapkan adalah data primer, diperoleh dari hasil wawancara dengan responden dan informan terkait yakni masyarakat Desa Serongga, Kepala Desa Serongga, Pengelola BSMP. Untuk teknik pengumpulan data dilakukan dengan datang langsung observasi ke lapangan untuk melihat secara langsung dan juga berinteraksi dengan warga sekitar untuk melihat kesempatan kerja apa saja yang telah tercipta dengan adanya BSMP

Teknik analisis data dilakukan dengan deskriptif kualitatif yaitu cara yang menekankan pada penggalian informasi yang kemudian hasilnya digambarkan dalam bentuk kata atau kalimat yang kemudian penyusunannya dilakukan secara teratur (sistematis) serta akurat mengenai fakta yang ada sehngga hasil terkait dengan perkembangan pariwisata dan pengaruhnya pada kesempatan kerja yang ada bagi masyarakat Desa Serongga

\section{HASIL DAN PEMBAHASAN}

Terhitung sudah sebelas tahun BSMP hadir ditengah-tengah masyarakat di Desa Serongga. Semenjak adanya rencana di bangunnya BSMP pihak pengelola sudah akan berjanji untuk melibatkan masyarakat lokal untuk ikut andil dalam proses pembangunan. Tepatnya pengerjaan dimulai pada tahun 2003. Dan diresmikan pada tahun 2007. PT. Taman Safari Indonesia selaku pengelola BSMP memahami betul pentingnya kontribusi dari masyarakat lokal untuk menjaga keberlangsungan daya tarik BSMP, untuk itu saat ini perlu ditinjau kembali kontribusi dalam bidang kesempatan kerja apa saja yang sudah tercipta.

Dengan lokasi yang mudah diakses dari berbagai daerah di Bali membuat BSMP menjadi tujuan rekreasi dari romobongan wisatawan maupun pribadi, untuk fasilitas yang disediakan pun sudah sangat lengkap dan beragam dan sudah dipastikan dapat mendukung kegiatan keperiwisataan.

Menurut data dari Dinas Pariwisata Kabupaten Gianyar jumlah kunjungan wisatawan domestik pada tahun 2016 tercatat sebesar 152.992 sedangkan untuk wisatawan mancanegara pada tahun yang sama yakni 
155.902. Dan berdasarkan sumber yang sama pendapatan yang diperoleh oleh BSMP pada tahun 2016 mencapai dua ratus milyar

\subsection{Kesempatan Kerja}

Dalam artikel ini kesempatan kerja yang dimaksud adalah kesempatan bagi seseorang atau angkatan kerja untuk memperoleh kesempatan bekerja. Tentunya semua orang akan berusaha untuk mendapatkan kesempatan kerja untuk memenuhi kebutuhan ekonomi mereka. Bisa dikatakan kesempatan kerja tercipta dari adanya kegiatan usaha yang dilakukan oleh swasta maupun pemerintah dalam bidang produksi maupun dalam bidang jasa. Berdasarkan penjalasan singkat diatas artikel ini akan membahas kesempatan kerja dengan adanya daya tarik wisata BSMP di Desa Serongga.

Berdasarkan dari hasil wawancara yang diperoleh dengan Bapak Anak Agung Udayana selaku kepala Desa Serongga menyampaikan terkait kesempatan kerja tersebut, beliau memaparkan kesempatan kerja dengan adanya BSMP sebetulnya sudah tercipta sebelum BSMP di bangun dimana setiap warga yang tanah nya diambil untuk proses pembangun BSMP akan mendapatkan pekerjaan secara langsung. Selain itu pihak Desa Serongga juga mendapatkan kemudahan jika ada salah satu warga mereka ingin mendaftar kerja di BSMP, pihak desa cukup membuatkan surat rekomendasi untuk calon pelamar.

Selain itu masih ada beberapa kemudahan yang diberikan oleh pengelola BSMP untuk memberikan kesempatan kerja bagi warga desa Serongga yakni bila BSMP membutuhkan pekerja pengelola akan mendahulukan warga Desa Serongga untuk mendapatkan kesempatan kerja tersebut, setelah itu barulah akan dibuka untuk umum. Selain beberapa kemudahan yang telah diberikan oleh BSMP, hingga saat ini sudah ada beberapa kesempatan kerja yang diperoleh dengan adanya BSMP, dan kesempatan kerja tersebut akan dipisah menjadi dua bagian yakni, kesempatan kerja langsung dan kesempatan kerja tidak langsung.

\subsubsection{Kesempatan Kerja Langsung}

Pengertian dari kesempatan kerja langsung disini

Adalah suatu sistem kerja dimana masyarakat Desa Serongga terlibat secara aktif dalam setiap operasional perusahaan, dimana disini pegawai terikat aturan dari pengelola BSMP, untuk jam kerjanya pun bisa 8 jam kerja maupun setengah hari kerja tergantung kontrak yang telah disetujui kedua belah pihak. Kesempatan kerja langsung terbagi mejadi dua, yaitu ;

1. Tenaga Kerja Kontrak di Bali Safari and Marine Park

Sejak BSMP mulai dibangun pada tahun 2002, dalam pengerjaanya sudah melibatkan peran dari masayarakat Desa Serongga itu sendiri, dimana masyarakat bekerja sebagai pekerja proyek di BSMP. Tepatnya pada tahun 2006 ketika BSMP akhirnya dibuka, pada saat itu pula 125 warga Desa Serongga memperoleh kesempatan kerja dalam beberapa bagian di BSMP dan hingga pada tahun 2017, dari total 509 orang pekerja di BSMP, 260 orang merupakan warga Desa Serongga. Masyarakat Desa Serongga terlibat sebagai pekerja di BSMP dalam berbagai bidang pekerjaan, diantaranya adalah 41 orang juru masak, 48 orang pawang hewan, 40 orang pegawai restoran, 60 orang pegawai hotel, 3 orang sebagai supir, 10 orang penjaga keamanan dan terdapat 23 orang petugas kebersihan. Para pekerja di BSMP dikontrak selama empat tahun dengan upah sesuai dengan standdar upah minimum di Kabupaten Gianyar, hal itu dikarenakan sampai saat ini pengelola BSMP hanya mempergunakan sistem kontrak dalam perekrutan karyawannya.

2. Pekerja Seni

Sebagai kebun binatang terbesar di Bali, BSMP tentu ingin menghadirkan suasana dan pelayanan yang lebih baik bagi para pengunjungnya. Hal ini direalisasikan dengan digelarnya pertunjukkan seni yang sekaligus sebagai sarana edukasi bagi para pengunjung BSMP terhadap seni dan budaya Indonesia khususnya Pulau Dewata Bali. Pementasan seni di BSMP diselenggarakan setiap hari meliputi beberapa jenis pementasan yang berbeda untuk memanjakan para pengunjung, salah satunya adalah pertunjukkan Teater Bali Agung yang dipentaskan oleh 100 oang pekerja seni di BSMP. Teater Bali Agung merupakan salah satu pertunjukan yang paling terkenal di BSMP, dimana pertunjukan ini telah memperoleh penghargaan sebagai Bali Leading Tourism Show.

Sanggar Paripurna memiliki andil besar dalam pementasan Teater Bali Agung oleh 100 orang pekerja seni. Sanggar Paripurna merupakan sanggar yang berasal dari Desa 
Bona, Gianyar. Meskipun sanggar ini tidak berasal dari Desa Serongga namun tetaplah memberikan kesempatan kerja bagi masyarakat Desa Seronga, hal ini dikarenakan 30 orang anggota sanggar Paripurna adalah masyarakat asli Desa Serongga, hal inilah yang menjadikan pementasan seni di BSMP juga memberikan kesempatan kerja bagi masyarakat Desa Serongga yang turut serta terlibat dalam pementasanya, khusunya bagi pemuda pemudi (truna truni) Desa Serongga.

Karena diadakan setiap hari, tentu BSMP memiliki pertunjukkan seni selain Teater bali Agung. Beberapa pertunjukkan seni lainnya meliputi pementasan Tari Baris Gede, Tari Topeng, pementasan Gamelan Bali atau biasa disebut rindik dan tersedianya berbagai oleholeh khas Bali bagi para pengunjung yang dijajakan oleh penjual oleh-oleh Gianyar khususnya dari Desa Serongga. Penampilan beberapa tarian diatas juga melibatkan partisipasi masyarakat Desa Serongga diantaranya 3 orang penari topeng, 5 orang penari baris gede, 3 orang juru gamelan dan 7 orang penjual oleh-oleh Bali. Keterlibatan masyarakat dalam pementasan tentu membuat masyarakat merasa terbantu sebab mereka dapat memperoleh pendapatan tambahan dari pekerjaan part time sebagai pekerja seni di BSMP.

\subsubsection{Kesempatan Kerja Tidak Langsung}

Kesempatan kerja tidak langsung merupakan kesempatan kerja yang diperoleh oleh mayarakat Desa Serongga dimana masyarakat disini tidak secara langsung terlibat dalam pekerjaan di BSMP, melainkan dapat disamakan dengan pekerjaan yang mendukung berlangsungnya kegiatan operasional di BSMP secara regular. Kesempatan sebagai pekerja pendukung kegiatan operasional di BSMP meliputi beberapa pekerjaan diantaranya adalah sebagai penyuplai pakan satwa dan penyedia konsumsi bagi staf di BSMP sebagai berikut:

1. Penyuplai Pakan Satwa

Kesempatan kerja tidak langsung sebagai penyuplai pakan satwa merupakan salah satu lapangan pekerjaan yang tersedia bagi masyarakat Desa Serongga. Masyarakat Desa Serongga memperoleh pendapatan dari pekerjaan sebagai penyuplai pakan untuk 400 satwa di BSMP yang untuk setiap harinya memerlukan cukup banyak pasokan makanan.
Pakan hewan yang disediakan oleh masyarakat Desa Serongga hanya dikhususkan bagi hewan herbivora, dimana pakan yang disediakan beragam, dapat berupa rumput gajah dan sayuran segar sebagai berikut:

a) Rumput Gajah

Rumput Gajah yang disediakan oleh masyarakat Desa Serongga bagi hewan herbivora di BSMP mencapai 5 ton per harinya. Hal ini dikarenakan banyaknya satwa herbivora yang terdapat di BSMP. Hal ini tentu menjadi lahan kesempatan bagi masyarakat yang ingin memperoleh pendapatan tambahan ataupun pendapatan pokok dengan bekerja sebagai penyuplai pakan satwa berupa Rumput Gajah ke BSMP. Dari Desa Serongga, pihak yang bertanggung jawab menjadi koordinator penyuplai rumput gajah ke BSMP adalah Bapak I Wayan Darmawan dari Banjar Serongga Kelod, hal ini diutarakan oleh Bapak Anak Agung Udayana sebagai Kepala Desa yang mengutus langsung pihak koordinator.

Dalam menjalankan tugas sebagai koordinator, tentu Bapak I Wayan Darmawan membutuhkan bantuan dari beberapa pihak untuk menjamin terlaksananya pengiriman rumput gajah ke BSMP berjalan lancar, dalam prosesnya bapak I Wayan Darmawan dibantu oleh seorang supir dan 10 orang pemotong rumput. Sebelumnya, pihak Desa Serongga masih memasok Rumput Gajah dari daerah lain di Bali untuk memenui permintaan Rumput Gajah yang begitu besar dari BSMP, daerah tersebut adalah Kintamani dan Mengwi. Namun saat ini, masyarakat Desa Serongga telah mandiri dalam penyediaan Rumput Gajah, hal ini dikarenakan kebutuhan akan Rumput Gajah begitu besar dan masyarakat dapat memperoleh keuntungan apabila membudidayakan Rumput Gajah itu sendiri. Sampai pada saat ini, masyarakat desa Serongga telah memiliki 5 hektar lahan Rumput Gajah dengan jumlah petani mencapai 60 orang.

Menurut penuturan Bapak Made Antara selaku petani Rumput Gajah di Desa Serongga, petani merasa diuntungkan dengan membudidayakan Rumput Gajah. Hal ini dikarenakan Rumput Gajah dapat dipanen dalam 3 bulan sekali, sehingga petani dapat memasok Rumput Gajah pada BSMP dan dapat mendapatkan pendapatan tambahan dibanding jika mereka menanam padi yang hanya dapat dipanen 1 tahun sekali dan harganya yang tidak 
begitu tinggi dibandingkan dengan harga Rumput Gajah yang senilai Rp 525,00 perkilo.

b) Sayuran Segar

Dalam penyediaan sayuran segar bagi hewan herbivora di BSMP, masyarakat Desa Serongga dapat mengajukan diri untuk menjadi pemasok sayuran segar. Sistem pemasok secara individu ini dicetuskan oleh salah satu petani dari Banjar Cebang Desa Serongga yakni Bapak I Nyoman Darmayasa. Beliau merupakan salah satu pemasok sayuran segar ke BSMP, yang meliputi beberapa jenis sayuran seperti sayur hijau dan wortel. Menurut penuturan Bapak I Nyoman Darmayasa, dalam hal penyediaan sayuran segar bagi hewan herbivora di BSMP beliau bekerjasama dengan beberapa petani dari Bedugul dan dalam pengiriminannya beliau dibantu 3 orang pegawai untuk memasok puluhan kilo sayuran segar yang didominasi oleh sayuran jenis wortel ke BSMP. Beberapa masyarakat Desa Serongga juga mulai menekuni bidang pekerjaan sebagai pemasok sayuran ke BSMP, hal ini dikarenakan kesempatan yang terbuka bagi semua pihak dan tentunya dapat memberikan penghasilan tambahan sehingga kesempatan kerja sebagai pemasok sayuran dimanfaatkan secara maksimal oleh masyarakat.

2. Penyedia Konsumsi bagi Staff di BSMP

Penyediaan konsumsi bagi staf di BSMP dilakukan oleh Depot Puri Agung. Depot Puri Agung merupakan penyedia konsumsi dikelola oleh Bapak Anak Agung Andara yang merupakan masyarakat Desa Serongga. BSMP sudah bekerjasama dengan Depot Puri Agung dalam hal penyediaan makanan kotak bagi para staf sejak tahun 2013. Penyediaan konsumsi bagi staf BSMP oleh Depot Puri Agung tidak hanya berdampak positif bagi perkembangan usaha depot sendiri, melainkan dapat membuka lapangan pekerjaan bagi masyarakat Desa Serongga sebagai tenaga kerja di Depot Puri Agung. Anak Agung Andara memaparkan bahwa Depot Puri Agung telah memiliki 20 karyawan yang merupakan masyarakat asli Desa Serongga. Tiap harinya Depot Puri Agung menerima pesanan 200 nasi kotak untuk konsumsi staf BSMP dengan harga nasi Rp $12.500,00$ per kotak. Penghasilan yang diperoleh oleh Depot Puri Agung juga disetorkan kepada Desa Serongga dalam bentuk uang kontribusi senilai Rp.500 per nasi kotaknya.
Dari penjelasan kesempatan kerja langsung maupun tidak langsung dapat di lihat bahwasanya BSMP telah memberikan kesempatan kerja yang cukup banyak dan bervariasi kepada masyarakat. Pada tabel di bawah ini akan ditampilkan secara lebih sederhana dan ringkas terkait jenis kesempatan kerja langsung maupun tidak langsung beserta juga dengan jumlah penyerapan tenaga kerja pada masing-masing jenis pekerjaan.

Tabel 1 Jumlah Kesempatan kerja langsung

\begin{tabular}{|l|l|c|}
\hline No & \multicolumn{1}{|c|}{$\begin{array}{c}\text { Kesempatan Kerja } \\
\text { Langsung }\end{array}$} & Jumlah \\
\hline 1. & Tenaga Kerja Kontra BSMP & 260 \\
\hline 2. & Pekerja Seni & 18 \\
\hline \multicolumn{2}{|c|}{ JUMLAH } & 278 \\
\hline
\end{tabular}

(Sumber: Kepala Desa Serongga)

Tabel 2 Jumlah Kesempatan kerja langsung

\begin{tabular}{|l|l|c|}
\hline No & $\begin{array}{c}\text { Kesempatan Kerja Tidak } \\
\text { Langsung }\end{array}$ & Jumlah \\
\hline 1. & Penyuplai Rumput Gajah & 71 \\
\hline 2. & Penyuplai Sayuran Segar & 4 \\
\hline 3. & $\begin{array}{l}\text { Penyedia konsumsi staff } \\
\text { BSMP }\end{array}$ & 21 \\
\hline \multicolumn{2}{|c|}{ JUMLAH } & 96 \\
\hline
\end{tabular}

(Sumber: Kepala Desa Serongga)

Penjelasan dari kedua tabel di atas memberikan penjelasan cukup sederhana mengenai kesempatan kerja apa saja yang telah tercipta dan juga jumlah tenaga kerja yang terserap dari Desa Seongga. Bila ditotal ada 374 orang masyarakat Desa Serongga yang terlibat langsung maupun tidak langsung dalam kegiatan suatu unit usaha yaitu BSMP. Tentunya diharapkan jumlah ini dapat terus meningkat sehingga nantinya tingkat kesejahteraan masyarakat Desa Serongga dapat meningkat.

\section{PENUTUP}

\subsection{Simpulan}

Dari hasil pembahasan yang telah diuraikan diatas, maka dapat diambil kesimpulan yaitu keberadaan Bali Safari And Marine Park di Desa Serongga memberikan dampak positif terhadap ketersediaan lapangan pekerjaan yang berdampak pada kesempatan kerja yang cukup beragam bagi masyarakat luas 
khususnya bagi masyarakat Desa Serongga. Untuk kesempatan kerja yang ada karena dampak dari keberadaan BSMP dibagi menjadi dua, yakni kesempatan kerja tidak langsung dan kesempatan kerja langsung. Kesempatan kerja langsung terbagi atas kesempatan kerja sebagai tenaga kerja kontrak dan sebagai pekerja seni di BSMP. Kesempatan kerja tidak langsung terbagi atas kesempatan kerja sebagai penyuplai pakan satwa berupa rumput gajah dan sayuran segar serta kesempatan kerja sebagai penyedia konsumsi bagi staf di BSMP.

\subsection{Saran}

Desa Serongga diharapkan agar lebih maksimal dalam mensosialisasikan dan memanfaatkan keberadaan BSMP untuk meningkatkan kesejahteraan masyarakat Desa Serongga. Disamping itu masyarakat diharapkan dapat memaksimalkan seluruh kesempatan yang disediakan oleh BSMP, baik itu kesempatan kerja langsung atau kesempatan kerja tidak langsung. Bagi BSMP, diharapkan agar kedepannya tetap konsisten dalam menjalankan kegiatannya dan programprogram yang bermanfaat bagi masyarakat sekitar, sehingga keberadaan BSMP bisa terus memberikan feedback bagi masyarakat Desa Serongga melalui berbagai kerjasama untuk mendukung kemajuan SDM dan Desa Serongga itu sendiri.

\section{DAFTAR PUSTAKA}

Anonim. 2009. Undang - Undang Republik Indonesia Nomor 10 Tahun 2009 tentang Kepariwisataan.

Adikampana, I Made 2012, “Optimalisasi Kontribusi Pariwisata Ceking Terhadap Ekonomi Masyarakat Lokal", Jurnal, Universitas Udayana.

Anggraeni, A. A. 2013. Analisis Pengaruh Ekonomi Wisata Bahari terhadap Pendapatan Masyarakat di Pulau Tidung. Reka Loka, Sripsi.

Bungin, Burhan. 2007. Metodologi Penelitian Kualitatif. Jakarta : PT. RajaGrafindo Persada.

Daldjoeni, N. 1987. Geografi Kota Dan Desa. Bandung : Alumni

Kusmayadi dan Sugiarto, Endar. 2000, Metode Penelitian dalam Bidang Kepariwisataan,Jakarta: PT Gramedia Pusataka Utama.

Moleong, L.J 2012 . Metodelogi Penelitian Kualitatif Edisi Revisi . Bandung PT Remaja Rosdakarya.

Sagir. 1994. Kesempatan Kerja dan Tenaga Kerja. www.filemakalah.ga/2014/08/kesempatankerja-dan-tenaga-kerja.html.

Wihasta, C. R., \& Prakoso, H. B. S. (2012). Perkembangan Desa Wisata Kembang Arum dan Pengaruhnya Terhadap Kondisi Sosial Ekonomi Masyarakat
Donokerto Kecamatan Turi. Jurnal Bumi Indonesia.

Yusuf, A Muri. 2014. Metode Penelitian Kuantitatif Kualitatif dan Penelitian Gabungan. Jakarta: Prenadamedia Group. 